AGRICULTURE AND BIOLOGY JOURNAL OF NORTH AMERICA

ISSN Print: 2151-7517, ISSN Online: 2151-7525, doi:10.5251/abjna.2013.4.1.1.5

(C) 2013, ScienceHuß, http://www.scihub.org/ABJNA

\title{
Hypoglyceamic activity of Alstonia boonei stem bark extract in mice
} *Akinloye, O.A., Oshilaja, R.T., Okelanfa O.A., Akinloye, D.I and ${ }^{1}$ O.M.O Idowu

Department of Biochemistry, Federal University of Agriculture, P.M.B 2240, Abeokuta, Nigeria.

${ }^{1}$ Department of Animal Nutrition, Federal University of Agriculture, P.M.B 2240, Abeokuta, Nigeria.

"Correspondence Author's Address: Dr Akinloye, O.A, Department of Biochemistry, Federal University of Agriculture, P.M.B 2240, Abeokuta, Nigeria., E-mail: oaakin@yahoo.com, Phone number: +2348030824063

\begin{abstract}
The present study was carried out to investigate hypoglycemic activity of Alstonia boonei stem bark extract in experimental mice. Forty mice divided into four (A, B, C and D) groups of ten mice per group were used. Group 1 served as control and were given distilled water in quantities equivalent to highest volume of extract administered while groups 2,3 and 4 were given streptozotocin (STZ) injection $(60 \mathrm{mg} / \mathrm{Kg})$, stem bark extract of $A$. boonei $(100 \mathrm{mg} / \mathrm{Kg}$ ) and glibenclamide $(2.5 \mathrm{mg} / \mathrm{Kg}$ bwt) respectively. Diabetes mellitus was induced in groups $B, C$ and $D$ by intraperitoneal injection of STZ $(60 \mathrm{mg} / \mathrm{Kg})$. The animals in group B were left untreated while those in groups $C$ and $D$ were administered aqueous stem bark extract $(100 \mathrm{mg} / \mathrm{Kg})$ of $A$. boonei orally by orogastric intubulation and glibenclamide $(2.5 \mathrm{mg} / \mathrm{Kg})$ respectively. The administration of the extract commenced two weeks post STZ injection and continued for four weeks. The mice in group $B$ (untreated diabetic) showed some behavioral changes ranging from sluggishness to polyuria which was also accompanied by reduced body weight and elevated blood glucose level. Administrations of $A$. boonei stem bark to diabetic group of mice (group C) caused a decrease in blood glucose level close to that of control and also reduced the specific activity of hepatic glucose-6- phosphatase (44\%) and fru-1, 6-phosphatase (40\%) with concomitant increased activity of glucose-6-phospahate dehydrogenase (30.5\%). These findings suggest that $A$. boonei stem bark extract possess hypoglyceamic properties via decreased production of regulatory hepatic glucogenic enzymes.
\end{abstract}

Keywords: Hypoglyceamic, Alstonia boonei, stem bark, mice.

\section{INTRODUCTION}

Alstonia boonei De Wild is large deciduous evergreen tree, usually up to $45 \mathrm{~m}$ tall and $1.2 \mathrm{~m}$ in diameter, belonging to the family Apocynaceae consisting of about $40-60$ species. It is a native of tropical and subtropical Africa, Southeast Asia, Central America and Australia. 'Alstonia' is named after Dr C. Alston (1685-1760), a Professor of Botany at Edinburgh University. It is also called 'devil tree' in tropical and sub-tropical Africa, Central America and Australia. It has been reported to be used for treatment of malaria, intestinal helminthes, rheumatism, muscular pain, insomnia, and hypertension. It has been reported to contain phytochemicals such as saponin, alkaloids, tannins and steroids (Taiwo et. al., 1998; Osadebe, 2002). In folk medical practice, an infusion of the extract of stem bark serves as anti-snake venom and as antidote to some arrows poisons. Antimalarial activity of various fractions of the stem bark extract of Alstonia boonei was reported by Bello et. al., (2009); lyiola, et. al., (2011) while Odugbemi and Akinsulire (2007), Idowu et.al., (2010) and Gbadamosi et.al., (2011) confirmed indigenous medicinal usefulness of Alstonia boonei for malaria therapeutic usage in Southwestern part of Nigeria. Oigiangbe et. al., (2010) reported insecticidal properties of an alkaloid from Alstonia boonei De Wild, while Olajide et. al., (2000) established anti-inflammatory, antipyretic and analgesic properties of $A$. boonei stem bark extract. However, potential nephrotoxicological effect, especially at high dose, was reported in Guinea pigs by Oze et.al., (2007). The stem bark of the plant has 
been reported to possess potent neuroleptic and anxiolytic properties in mice (Elizabetsky and CostaCampos, 2006) and also to contain important minerals like calcium, phosphorous, iron, sodium, potassium and magnesium in addition to alkaloids, tannins, saponins, flavonoids, cardiac glycoside and vitamin C. More so, Elijah et. al., (2010) reported possible and promising beneficial effect of $A$. boonei for preserving palm wine.

Hyperglyceamic syndrome and its associated biochemical and morphological changes have been reported to be a life threatening condition with resultant complex and multifarious groups of disorders with vascular and renal dysfunctions. All over the continent, the prevalence of hyperglyceamia has been on the increase day by day, not only because of genetic factor/reason but also due to individual lifestyle, thus becoming one of the major causes of death especially in developing countries. Although, medicinal importance of stem bark extract of $A$. boonei in ameliorating some disease conditions has been reported by several authors, however, to the best of our knowledge, there is dearth of information on the effect of this plant on blood glucose level. In an attempt to carry out further scientific scrutiny on this plant, this study was therefore carried out to investigate possible hypoglyceamic properties of the stem bark extract of A. boonei in mice.

\section{Materials and Methods}

Animals: Forty (40) mice weighing between 26-28g were purchased from the National Institute of Veterinary Research and Training, Yaba, Lagos, Nigeria. They were kept in well ventilated animal cages under good hygienic condition that allows continuous airflow and exposure to $12 \mathrm{hrs}$ light/dark cycle. They were allowed to acclimatize for two weeks and allowed free access to feed and water ad libitum. They were randomly divided into four (A, B, C and D) groups of ten rats in each. Group A served as control and were given water and feed only, group $B$ were streptozotocin (STZ) -induced diabete mellitus mice- untreated, group C were streptozotocininduced mice treated with $100 \mathrm{mg} / \mathrm{Kg}$ body weight of the $A$. boonei stem bark extract while group $D$ were streptozotocin - induced diabetes mellitus - treated with $2.5 \mathrm{mg} / \mathrm{Kg}$ body weight of glibenclamide. The handling and care of the mice were conducted in strict compliance with humane animal care standard outlined in the 'Guide to the Care and Use of Laboratory Animals in Research and Teaching' prepared by the National Institute of Health $(\mathrm{NIH})$, publication 86-23 (revised in 1985). Approval of the Departmental ethical committee was obtained before the commencement of the experiment.

Plant material: Fresh stem barks of $A$. boonei were harvested from local garden at Odeda, Odeda Local Government Area, Ogun-State, Nigeria. It was identified and authenticated by $\mathrm{Dr}$ D.O Aworinde (Plant Taxonomist) of the Department of Biological Sciences (Botany Unit), Federal University of Agriculture, Abeokuta, Nigeria.

Preparation of $\boldsymbol{A}$. boonei stem bark extract: Fresh stem bark of $A$. boonei were cut into smaller pieces and were air-dried at room temperature. One thousand gram $(1000 \mathrm{~g})$ of the air-dried stem bark of the plant was milled into fine powder using commercial blender. The powdered stem bark was exhaustively extracted two times with two litres (2L) of distilled water for $12 \mathrm{hrs}$ by maceration following traditional method. The combined aqueous extracts soluble were concentrated to dryness under reduced pressure at $50 \pm 1^{\circ} \mathrm{C}$ in a rotator evaporator. The resulting crude dark-brown powdered residual extract gave a percentage yield of $5.81 \%$.

Induction of Experimental Animal: Diabetes mellitus was induced in groups $B$ and $C$ according to the method described by Chowdhury et al., (2012). Briefly, STZ was dissolved in physiological saline and thereafter administered by intravenous injection (through tail vein) to $12 \mathrm{hrs}$ fasted mice at a dose of $60 \mathrm{mg} / \mathrm{Kg}$ body weight. Group 1 (control) were injected with volume of distilled water equivalent to the volume of STZ administered intraperitoneally to other groups of mice.

Administration of $\boldsymbol{A}$. boonei stem bark extract: Baseline blood glucose levels were obtained from all mice before the commencement of the experiment by cutting the tail tip using Acucheck Glucometer and compatible blood glucose test strips. Fasted streptotozin-induced mice with blood glucose concentration greater or equal to $18 \mathrm{mmoll}^{-1}$ were considered to be diabetic and used in this study. One hundred milligram per kilogram body weight (100 mg/Kg b.wt) of $A$. boonei stem bark extract was administered to group $\mathrm{C}$ mice only.

Blood samples were collected from the tail vein of each mouse on the $2^{\text {nd }}, 5^{\text {th }}$ and $8^{\text {th }}$ day of the experiment for the estimation of blood glucose concentration following glucose oxidase method of Trinder as described by Lott and Turner (1975). 
Glucose-6-phosphate dehydrogenase activity in the hepatocyte was determined by the method of Olive and Levy (1975) while the fructose1, 6-bisphosphate and glucose -6-phosphatase activities were determined by the methods of Bergmeyer et.al., (1987) and Nordlie and Arion (1966) respectively while the inorganic phosphate liberated was determined by the modified Fiske and Subbarow method of Yuen and Pollard (1951).

Protein concentration was determined according to the methods of Lowry et.al., (1951).

Statistical Analysis: Data generated were expressed as mean ( \pm SEM) and analyzed using repeated measure of variance. The differences between the means were analyzed statistically with one way analysis of variance (ANOVA; 95\% confidence interval) followed by Duncan Multiple Range Test. Values of $\mathrm{p}<0-05$ were considered statistical significance.

\section{RESULTS}

General observable characteristics of the mice: It was observed that all the control mice were moving freely throughout the period of experimentation. The diabetic mice were sluggish and appeared highly lethargic. The blood glucose level of diabetic mice was significantly $(p<0.05)$ higher than that of other groups and was also accompanied by significant reduced body weight.

The mean blood glucose concentrations of all the mice in each experimental group are shown in table 1. In control group of mice, administration of distilled water alone did not cause any significant alteration in the blood glucose concentrations. Induction of diabetes with STZ resulted in significant increases in the blood glucose levels of the mice. A gradual increase in the blood glucose level was observed from the day 1 after the injection of STZ. There was no significant different in the blood glucose concentrations of the control group and group of mice administered glibenclamide. Administration of $A$. boonei at $100 \mathrm{mg} / \mathrm{Kg}$ reduced the blood glucose concentrations close to that of control.

Table 1: Blood glucose concentrations of control and experimental mice.

\begin{tabular}{|c|c|c|}
\hline Groups & Treatments & $\begin{array}{l}\text { Mean Glucose } \\
(\mathrm{mmol} / \mathrm{l})\end{array}$ \\
\hline 1- Control & Distilled water alone & $9.35 \pm 0.32^{a}$ \\
\hline $\begin{array}{ll}\text { 2- } & \text { Diabetic } \\
& \text { (untreate }\end{array}$ & $\begin{array}{l}\text { STZ injection (60mg/ } \\
\mathrm{Kg})\end{array}$ & $14.40 \pm 0.70^{b}$ \\
\hline $\begin{array}{ll}\text { d) } \\
\text { 3- } & \text { Diabetic } \\
\text { (treated) }\end{array}$ & $\begin{array}{l}\text { Extract of } A \text {. boonei } \\
(100 \mathrm{mg} / \mathrm{Kg})\end{array}$ & $8.62 \pm 0.65^{a}$ \\
\hline 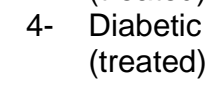 & $\begin{array}{l}\text { Glibenclamide } \\
(2.5 \mathrm{mg} / \mathrm{Kg}) \text {. }\end{array}$ & $4.11 \pm 0.21^{c}$ \\
\hline
\end{tabular}

Values with different superscript along the same column are significantly different at $p<0.05$.

The effect of A.boonei stem extract on some enzymes in glucose metabolic pathway is shown in table 2.

A. boonei stem bark aqueous extract cause about $44 \%$ and $40 \%$ reduction in the activities of hepatic glu-6-phosphatase and fru-1, 6-phosphatase respectively. This was accompanied by about $30.5 \%$ increase in glu-6-phosphate dehydrogenase.

Table 2: Effect of A.boonei stem extract on some enzymes of glucose metabolic pathway.

\begin{tabular}{|l|c|c|c|}
\hline & \multicolumn{3}{|c|}{ Enzymes } \\
\hline Groups & $\begin{array}{l}\text { Glu-6-phosphatase } \\
\text { (units/mg) }\end{array}$ & $\begin{array}{l}\text { Fru-1,6 -bisphosphatase } \\
\text { (units/mg) }\end{array}$ & $\begin{array}{l}\text { Glu-6-phosphatase } \\
\text { dehydrogenase (units/mg) }\end{array}$ \\
\hline Diabetic (untreated) & $1.89 \pm 0.11$ & $0.27 \pm 0.020$ & $220 \pm 18.5$ \\
Diabetic (treated) & $3.20 \pm 0.14$ & $0.45 \pm 0.034$ & $153 \pm 9.36$ \\
Diabetic (treated) & $2.60 \pm 0.09$ & $0.31 \pm 0.031$ & $188 \pm 11.4$ \\
Glibenclamide & $2.10 \pm 0.11$ & $0.24 \pm 0.022$ & $214 \pm 15.6$ \\
\hline
\end{tabular}

\section{DISCUSSION}

The present decade has witnessed a tremendous and intense resurgence in the interest and use of medicinal plant and medicinal plant products, especially in Africa and North America. The beneficial effects of these plant materials has been attributed to the combinations of secondary metabolites present in 
the plant (Briskin, 2000). The healing power of herbs has been recognized and botanic medicine has been one of the oldest practiced professions by mankind (Oduola et al., 2007). In recent times, hyperglyceamia and its associated health related complications such as diabetic mellitus have been on the prowl. In fact, the use of synthetic pharmaceutical products and hypoglyceamic agent has been reported not only to be associated or accompanied by some serious adverse effects but these drugs are costly and not within the reach of all. Thus, a dire need for the development of cheap, effective, safe and readily available hypoglyceamic agents from plants and other natural sources. In fact, traditional of using herbs to promote healing is not an alien in any continent. In an effort to shed light on possible hypoglyceamic effects of the stem bark extract of $A$. boonei, the present investigation was undertaken.

The therapeutic importance of the extract of the stem bark of $A$. boonei in folk medicine has been documented (Hobbs, 1993). Apart from the paucity of information regarding the adverse or toxicity of this plant extract in spite of its wide spread usage in folk medicinal/traditional practice, there is dearth of information underlying biochemical mechanism responsible for some of the observable and reported properties of this plant. The results of the present study indicate that $A$. boonei stem bark extract caused a significant reduction in the blood glucose levels of diabetic mice. Although, the exact mechanism behind this observed hypoglyceamic action/effect remains speculative at present, previous phytochemical studies of this plant have indicated the presence of chemical compounds such as saponin, alkaloids, tannins and steroids (Taiwo et. al., 1998; Osadebe, 2002; Osawe et.al., 2007; Odeku, 2008) This may be responsible since a number of investigator have shown that plant polyphenolic compounds and host of other plant secondary metabolites possess hypoglyceamic, hypotensive and other pharmacological properties in various experimental animal models (Ojewole et.al., 2011; Akah and Okafor, 1992). Therefore, it could be suggested that some of these phytochemicals are probably responsible for the observable reduced blood glucose level in the groups of mice administered with the plant extract.

However, the proposed mechanism for the observable hypoglycemic effect of the A.boonei stem bark extract (at the tested dose) in the mice could be attributed to the reduction in the activity of the regulatory hepatic glucogenic enzymes namely glucose-6-phosphatase and fructose-1,6bisphospahtase. As a result of reduced activities of these enzymes, it could be inferred that glucose synthesis would be decreased, thus, reducing the blood glucose level in these mice. More so, increase in the activity of glucose -6-phosphate dehydrogenase observed when the A.boonei extract was administered could be assumed to be responsible for the increase glucose metabolism through hexose monophosphate shunt. The resultant possible overall effect could therefore be attributed to the blood glucose decreasing effect of the extract in diabetic-induced rat, in that, the hypoglyceamic effect caused by this plant is partially mediated through the decrease production of glucose by the process of gluconeogenesis in the liver. Meanwhile, further work is in progress to investigate the mechanism behind the modulatory effects of this plant extract on the enzymes of glucose metabolism as well as possible potentiating effect of A.boonei extract on pancreatic secretion of insulin from the $B$-cell of islet of Langerhans.

\section{REFERENCES}

Adewole, S.O., Adenowo, T.K., Thajasvaric, N. and Ojewole, A.O (2011). Hypoglyceamic and hypotensive effects of Ficus exasperate Vahl (Moraceae) leaf aqueous extract in rats. Afr. J. Tradit. Complement Altern. Med. 8(3): 275-283.

Akah, P.A and Okafor, C.L (1992). Blood glucose loweing effect of Vernonia amygdalina (Del) in an experimental rabbit model. Phytother. Res. 6:171-173.

Akinmoladun, A.C., Ibukun,E.O., Afor,E., Akinrinola, B.L., Onibon,T.R., Akinboboye, A.O., Obuotor, E.O and Farombi, E.O (2007). Chemical constituents and antioxidant activity of Alstonia boonei. Afr. J. Biotechnol. 6(10): 1197-1201

Bello, I.S., Oduola,T., Adeosun,O.G., Omisore, N.O.A., Raheem, G.O. and Ademosun, A.A (2009). Evaluation of antimalarial activity of various fractions of Morinda lucida and Alstonia boonei stem bark. Global J. Pharmacol. 3(3): 163-165.

Bergmeyer, H.U., Bergmeyer, J and Grassi, M (1987). Methods in Enzymatic Analysis, $3^{\text {rd }}$ ed Vol. VI Verlag Chemie, Weinheim Germany.

Briskin, D.P (2000). Medicinal Plants and Phytomedicine. Linking Plant Biochemistry and Physiology to Human Health. Plant Physiology, 124: 507-514.

Chowdhury, M.D.A., Hossain, M.I., Hossan, M.D.S., Ahmed, S., Afrin, T and Karim, N (2012). Antidiabetic effects of Momordica charantia (Karela) in male long evans rats. J. Adv. Lab. Res. Biol. 3(3): 207-212. 
Elijah, A.I., Ojimelukwe, P.C., Ekong,U.S and Asamudo, N.U (2010). Effect of Sacoglottis gabonesis and Alstonia boonei on the kinetic of Saccharomyces cerevisae isolated from palm wine. Afr. J. Biotechnol. 9(35): 5730-5734.

Elisabetsky, E and Costa-Campos, L (2006). The alkaloid alstonine: a review of its pharmacological properties. Evidence-Based Complementary and Alternative Medicine, 3(1): 39-48.

Gabriel, O., Harrision, N., Okey, O and Ukoha, (2008). Changes in lipid and haematological profile of aqueous ethanolic extract of Astonia boonei in rats. The Internet J.of Haematology, 4(11): 551-557.

Gbadamosi, I.T., Moody, J.O and Lawal, A.M (2011). Phytochemical screening and proximate analysis of eight ethnobotanicals used as antimalaria remedies in Ibadan. Nig. J. Appl. Biosci. 44: 2967-2971.

Hobbs, C.E (1993). Alstonia boonei plant, In: Handbook of African Medicinal Plants, $3^{\text {rd }}$ ed. C.R.C Prss, Boca, Rota F.L. pg 116-118.

Idowu, O.A., Soniran, O.T., Ajana, O and Aworinde, D.O (2010). Ethnobotanical survey of antimalarial plants used in Ogun State, Southwest, Nigeria. Afr. J. Phar. Pharmacol. 4: 055-060.

Iyiola, O.A., Tijani, A.Y and Lateef, K.M. (2011). Antimalarial activity of ethanolic stem bark extract of Alstonia boonei in mice. Asian J. Biol. Sci. 4: 235-243.

Lott, J.A and Turner, K (1975). Evaluation of Trinder's glucose oxidase method for measuring glucose in serum and urine. Clin. Chem. 21(12): 1754-1960.

Lowry, O.H., Rosebrough, N.T., Far, A.L and Randall, R.J (1951). Protein measurement with folin phenol reagent. J. Biol. Chem. 193: 265-275.
Nordlie, R.C and Arion, W.J (1966). Methods in Enzymology, 9: 619-625.

Oigiangbe, O.N., Igbinosa, I.B and Tamo, M (2010). Insecticial properties of an alkaloid from Alstonia boonei De Wild. J. Biopesticides. 3(1): 265-270.

Odugbemi, T.O and Akinsulire, O.R (2007). Medicinal plants useful for malaria therapy in Okeigbo, Ondo State, Southwest, Nigeria. Afr. J. Trad. CAM. 4(2): 191-198.

Olajide, O.A., Awe, S.O., Makinde, J.M., Ekhelar, A.I., Olusola, A., Morebise, O. and Okpako, D.T (2000). Studies on the anti-inflammatory, antipyretic analgesic properties of Alstonia boonei stem bark. J. Ethnopharmacol. 71(1-2): 179-186.

Osadebe, P.O (2002). Anti inflammatory properties of the root bark of Alstonia boonei. Nig. J. Nat. Prdt. Med. 6: 39-41.

Oze, G.O., Nwanjo, H.U. and Onyeze, G.O (2007). Nephrotoxicty caused by the extract of Alstonia boonei (De Wild) stem bark in Guinea pigs. The Internet J. Nutr. and Wellness, 3(2): 1-9.

Taiwo, O.B Taiwo, O.B., Kroes, B.H., Beukelman, C.J., Horsten, S., Horsten, S., Horsten, S., Makinde, J.M and Labadie, R.P (1998). Activity of the stem bark extract of Alstonia boonei de Wild (Apocynaceae) on human complement and $A$ polymorphonuclear leukocytes. Ind. J. Pharmacol. 30: 169-174.

Yuen, S.H and Pollard, A.G (1951). The Fiske Subbarow method for determining phosphate with special reference to soil extract. J. of Sci. Food and Agric. 2(1): 36-42. 